\title{
PROFESI GURU DALAM SEBUAH PROFESI KEPENDIDIKAN
}

\author{
Intan Noor Azizah \\ Email: $1910128220022 @$ mhs.ulm.ac.id \\ Program Studi Pendidikan IPS Fakultas Keguruan dan Ilmu Pendidikan \\ Universitas Lambung Mangkurat \\ Banjarmasin
}

\begin{abstract}
Abstrak
Profesi guru adalah profesi yang mengharuskan adanya persyaratan khusus teruntuk calon pendidik atau yang sering disebut dengan guru di sekolah. Profesi adalah keahlian yang hanya dimiliki oleh orang tertentu melalui akademik dan latihan yang intensif dan memiliki syarat yang harus dipenuhi jika ingin pekerjaan dianggap sebagai profesi. Pemaparan tersebut terdapat dalam Undang-Undang yang menjelaskan bahwa guru harus mempunyai kualifikasi akademik S1 atau setara dengan Diploma IV dan sertifikat pendidik. Selain hal yang telah disebutkan tadi, guru juga harus mempunyai kompetensi Pedagogik, Kepribadian, Sosial, dan Profesional. Dalam Undang-undang Nomor 14 Tahun 2005 tentang Guru dan Dosen mengatakan bahwa guru adalah pendidik profesional dengan tugas utama mendidik, mengajar, membimbing, mengarahkan, melatih, menilai, dan mengevaluasi peserta didik. Oleh sebab itu, menjadi seorang guru bukan pekerjaan yang mudah.
\end{abstract}

\section{PENDAHULUAN}

Profesi merupakan pekerjaan yang memerlukan pelatihan dan penguasaan terhadap suatu pengetahuan khusus. Pada umumnya suatu profesi mempunyai organisasi profesi, kode etik, serta proses sertifikasi dan lisensi yang khusus untuk bidang profesi tersebut. Secara etimologi, istilah profesi berasal dari kata bahasa Inggris profession yang bersumber dari bahasa Latin profesus yang artinya mampu atau ahli dalam suatu bentuk pekerjaan. Bisa disimpulkan bahwa profesi adalah satu pekerjaan ataupun jabatan yang menuntut kita 
memiliki keahlian yang diperoleh dari pendidikan ataupun latihan tertentu dengan syarat yang khusus yaitu mempunyai tanggung jawab dan berdasarkan kode etik tertentu. Pekerjaan ini biasanya bersifat profesional berbeda dengan pekerjaan lainnya yang hanya memerlukan kemampuan dan keahlian khusus dalam pelaksanaan profesinya tersebut. Hanya pekerjaan-pekerjaan tertentu bisa disebut profesi dikarenakan adanya syaratsyarat khusus yang wajib dipenuhi sehingga sebuah pekerjaan itu bisa dikatakan profesi. Suatu pekerjaan dapat dikatakan profesi ketika memiliki spesialisasi ilmu, terdapat kode etik dalam melaksanakan profesi, memiliki organisasi profesi, diakui masyarakat, karir sepanjang hayat, dilengkapi kecakapan diagnostik, dan mempunyai klien yang jelas. Hal tersebut merupakan syarat mendasar suatu pekerjaan dapat digolongkan menjadi suatu profesi. Tiap-tiap profesi mempunyai syarat kompetensi tertentu dan terdapat kelengkapan profesi seperti kode etik dan organisasi. (Susanto, 2020: 11-13). Menurut Undang-Undang Republik Indonesia No.14 tahun 2005 tentang Guru dan Dosen Pasal 1, Guru adalah pendidik profesional dengan tugas utama mendidik, mengajar, membimbing, mengarahkan, melatih, menilai, dan mengevaluasi peserta didik pada pendidikan anak usia dini jalur pendidikan formal, pendidikan dasar, dan pendidikan menengah. (Susanto, 2020: 13). Guru termasuk suatu profesi dikarenakan merupakan suatu jabatan yang memerlukan keahlian khusus sebagai guru dan tidak dapat dilakukan oleh sembarang orang diluar bidang pendidikan. Seorang guru harus tahu serta bisa mengaplikasikan prinsip mengajar yang ada supaya bisa melaksanakan tugas dengan profesional.

\section{PERAN GURU SEBAGAI SEBUAH PROFESI}

Guru merupakan sebuah profesi. Guru termasuk suatu profesi dikarenakan merupakan sebuah pekerjaan yang memerlukan keahlian khusus sebagai guru dan tidak sembarang orang dapat melakukan pekerjaan tersebut diluar pendidikan. Guru membutuhkan syarat tertentu yang didapatkan melalui pendidikan yang disusun secara khusus sekiranya guru tidak berbuat kesalahan pada saat melaksanakan tugasnya yang akan berakibat pada masa depan peserta didik serta merugikan ranah pendidikan. Oleh sebab itu guru membutuhkan pendidikan yang profesional agar bisa menghasilkan pendidik yang 
mempunyai kemampuan profesional yang disyaratkan jabatan guru sebagai suatu profesi. (Gaffar, 2017: 2).

Dalam UU No.14 tahun 2005 mengenai Guru dan Dosen bertujuan untuk membangun profesionalitas guru. Memberdayakan dan membantu peningkatan kualitas seorang tenaga pendidik (guru) secara terstruktur demi tercapainya profesi guru yang bermartabat dan sejahtera. Dalam UU ini juga tenaga pendidik diwajibkan mengikuti organisasi profesi, guru wajib menaati kode etik profesi,dan guru dapat perlindungan dari pemerintah (Komara, 2016). Dengan lahirnya UU tersebut, secara tersirat ditegaskan bahwa pekerjaan seorang guru ditetapkan sebagai sebuah profesi. Tindak lanjutnya akan dilakukan sertifikasi yang bertujuan untuk memilah yang mana guru yang sudah profesional dan mana yang belum profesional.

\section{GURU INDONESIA DAN TANTANGAN PROFESIONALISME}

Dalam proses pendidikan, guru berfungsi mengajar, membina, mendidik, mengarahkan dan membentuk watak serta kepribadian sehingga peserta didik dapat berubah menjadi manusia yang lebih baik lagi yang memiliki ilmu pengetahuan, cerdas, dan bermartabat. Guru merupakan peran yang pas dan tidak dapat digantikan oleh apapun untuk pemberdayaan dan pembelajaran suatu bangsa sejak dari dahulu. Semakin terlihatnya potensi seorang guru dalam menjalankan tugas maupun perannya, maka semakin terjamin pula kehandalan maupun terbina nya seorang guru tersebut dalam hal kesiapannya menjadi seorang guru baik. Dapat kita simpulkan bahwa gambaran manusia yang akan datang akan tercermin dari bagaimana gambaran guru yang ada di masa sekarang dan gerak menuju kehidupan tersebut sangat tergantung pada bagaimana guru dan perannya di tengah masyarakat. (Susanto, 2020: 16).

Undang-Undang RI Nomor 14 Tahun 2005 pasal 1 nomor 10 tentang Guru dan Dosen memaparkan bahwa kompetensi merupakan seperangkat pengetahuan, keterampilan, dan perilaku yang harus dimiliki, dihayati, dan dikuasai oleh guru atau dosen dalam melaksanakan tugas keprofesionalan. Kompetensi guru merupakan perpaduan antara kemampuan personal, keilmuan, teknologi sosial, dan spiritual yang secara totalitas

membentuk kompetensi standar profesi guru, yang mencakup penguasaan materi, pemahaman terhadap peserta didik, pembelajaran yang mendidik, pengembangan pribadi 
dan profesionalisme. Kompetensi terbagi menjadi empat macam yaitu, kompetensi pedagogik, kompetensi kepribadian, kompetensi profesional, dan kompetensi sosial. (Ulinnuha, 2019: 27)

Adapun komponen yang wajib dipunya oleh seorang guru supaya bisa disebut guru yang profesional yaitu: menurut Cooper (1984: 15) dalam Susanto (2020: 63) menyatakan :

1. Memiliki intelektual mengenai pembelajaran dan sikap manusia.

2. Memiliki cara dalam pembelajaran berupa teknik yang efisien.

3. Mampu memposisikan diri di sekolah, teman sejawat, dan dikelas.

4. Memiliki pengetahuan yang ia kuasai dibidang yang ia ajar

\section{SIMPULAN}

Tidak semua profesi dapat dikatakan sebuah profesi dikarenakan adanaya persyaratanpersyaratan khusus yang wajib dipenuhi agar dapat disebut sebagai profesi. Guru termasuk profesi dikarenakan merupakan sebuah pekerjaan yang memerlukan keahlian khusus sebagai guru dan tidak sembarang orang dapat melakukan pekerjaan tersebut diluar pendidikan. Oleh sebab itu guru memerlukan pendidikan profesional yang bisa menghasilkan kemampuan profesional yang disyaratkan oleh jabatan guru sebagai sebuah profesi. Tindak lanjutnya akan dilakukan sertifikasi yang bertujuan untuk memilah yang mana guru yang sudah profesional dan mana yang belum profesional. Dan guru berfungsi mengajar, membina, mendidik, mengarahkan dan membentuk watak serta kepribadian sehingga peserta didik dapat berubah menjadi manusia yang lebih baik lagi yang memiliki ilmu pengetahuan, cerdas, dan bermartabat.

\section{REFERENSI}

Efendi, I., Prawitasari, M., \& Susanto, H. (2021). Implementasi Penilaian Pembelajaran Pada Kurikulum 2013 Mata Pelajaran Sejarah. Prabayaksa: Journal of History Education, 1(1), 21-25.

Gaffar, M. F. (2017). Guru Sebagai Profesi. Jurnal Administrasi Pendidikan, 5(1).

Komara, E. (2016). Perlindungan Profesi Guru di Indonesia. Mimbar Pendidikan, 1(2). 
Ulinnuha, A. A. (2019). kompetensi kepribadian guru perspektif ki hadjar dewantara perspektif undang-undang nomor 14 tahun 2005 tentang guru dan dosen (Doctoral dissertation, IAIN Ponorogo).

Susanto, H. (2020). Profesi Keguruan. Banjarmasin: FKIP Universitas Lambung Mangkurat.

Susanto, H., \& Akmal, H. (2018). Efektivitas Penggunaan Aplikasi Pembelajaran Berbasis Mobile Smartphone Sebagai Media Pengenalan Sejarah Lokal Masa Revolusi Fisik Di Kalimantan Selatan Pada Siswa Sekolah Menengah Atas. HISTORIA: Jurnal Program Studi Pendidikan Sejarah, 6(2), 197-206.

Susanto, H., Irmawati, I., Akmal, H., \& Abbas, E. W. (2021). Media Film Dokumenter Masuknya Islam Ke Nusantara dan Pengaruhnya Terhadap Keterampilan Berpikir Kritis Siswa. HISTORIA: Jurnal Program Studi Pendidikan Sejarah, 9(1). Syaharuddin, S., \& Susanto, H. (2019). Sejarah Pendidikan Indonesia (Era Pra Kolonialisme Nusantara sampai Reformasi). Banjarmasin: FKIP Universitas Lambung Mangkurat. 